\title{
ALEXANDER THEODOR VON MIDDENDORFF - DOCTOR, EXPLORER AND PROMOTER OF CATTLE-BREEDING
}

\author{
MaIe Toomsalu \\ Institute of Anatomy, University of Tartu
}

\begin{abstract}
Alexander Theodor von Middendorff is considered one of the most pioneering scientists. As a talented researcher, Alexander Theodor von Middendorff made his contribution to the development of geography, hydrology, climatology, botany, glaciology, zoology, agriculture, ethnography (partly even linguistics) and other sciences. Along with K. E. von Baer, Alexander Theodor von Middendorff was one of the greatest naturalists in $19^{\text {th }}$-century Russia. Like Baer, Middendorff represents the type of naturalists who, in addition to encyclopaedic knowledge, had deep erudition and were able to contribute to several fields.
\end{abstract}

Keywords: geography; hydrology; climatology; botany; glaciology; zoology; agriculture; ethnography

\section{FORMATIVE YEARS}

Alexander Theodor von Middendorff was born on 18 August 1815 (New Style) (6 August 1815 Old Style) in the family of Theodor Johann von Middendorff (1776-1856), Professor, later Director of St Petersburg Pedagogical Institute. The first nine years of his life, Alexander Theodor von Middendorff spent with his Estonian mother at Pööravere manor, which belonged to his father, and Tallinn. Until 1824, he was home-schooled in Tallinn by private tutors. In 1824, his parents married and Alexander was taken to St Petersburg. From 1824-1828, he studied at St Petersburg $3^{\text {rd }}$ Gymnasium and at a private school. After that, he attended the preparatory courses of St Petersburg Pedagogical Institute until 
1832. Simultaneously, he worked as a secretary at the Department of Manufacturing and Domestic Trade. His school holidays, however, were spent at Hellenurme manor. There he gained experience in agriculture, handicraft and hunting. Already as a youngster (by his $10^{\text {th }}$ birthday), he got a hunting gun from his father as a present and became an excellent marksman and a good hunter [2: 4, 9: 13]. He loved to roam in the forests and bogs of Livonia [12: 16].

In January 1832, he entered the Faculty of Medicine at the University of Tartu (Dorpat). At that time, Dorpat University was the best university in Russia by its staff of professors and quality of teaching. Middendorff was not

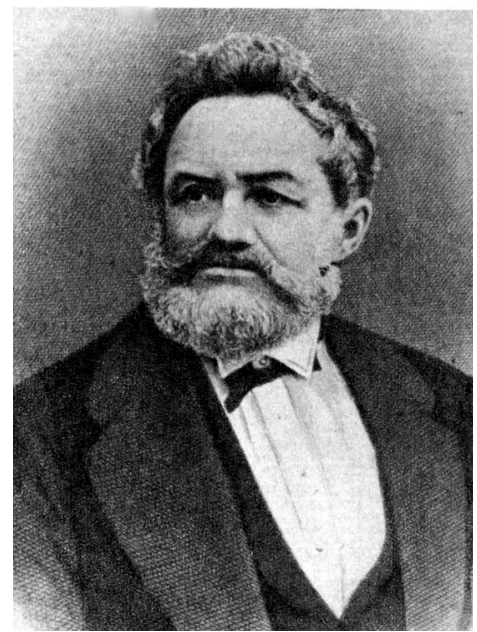

Academician Alexander von Middendorff. a member of any student fraternity. The few friends he had were honest and noble; in addition, they were passionate hunters. The house where Middendorff and his friend Vilken lived was called the "hunter's lodge". Middendorff and his friends V. Bötlingk, A. I. Schrenk and J. I. Stubendorf dreamed of travelling and were interested in palaeontology and geology. They were frequent guests at Professor A. F. Hueck's home [12]. In 1837, he graduated from the university by successfully defending his doctoral dissertation written under the supervision of Martin Heinrich Rathke. The theme of his doctoral dissertation was D quaedam de bronchorum polypis, morbi casu observato illustrata (Five hundred illustrated cases of the bronchial polyp) [11: 192]. For the epigraph of his doctoral dissertation, he chose Chamisso's saying: "For a traveller, the skills of a doctor are necessary not only for rendering help to himself and his companions but also for creating friendly relations with the local population" [9: 13]. On 2 June 1837, he received his doctor's diploma. He was fluent in German, Russian, French and Estonian. After graduation, he upgraded his knowledge of natural sciences at the universities of Breslau, Vienna and Berlin where he studied under famous professors of that time. He continued relations with several of them after returning to St Petersburg [12: 19].

When he returned in 1839, he did not have any concrete plans. Although he dreamed of travelling, he had to find a permanent job. Supported by Hueck, Middendorff had an opportunity to get a position in Kharkiv, but this did not suit him. Next, Kiev University was mentioned in correspondence with 
Baer [12: 21]. In 1839, Middendorff became Adjunct Professor of Zoology at Vladimir University in Kiev. He lectured on ethnography, general zoology and zoology of vertebrates at the Second Department of the Faculty of Philosophy and on some parts of the zoology course at the Faculty of Medicine. He also collected material for the future study room of zoology [12:21]. University life was not to his liking; he would have liked to go to Dorpat University, but there was no vacancy for a zoologist.

In 1850, he married Hedwig Elisabeth von Hippius (1825-1868) in St Petersburg, and they had

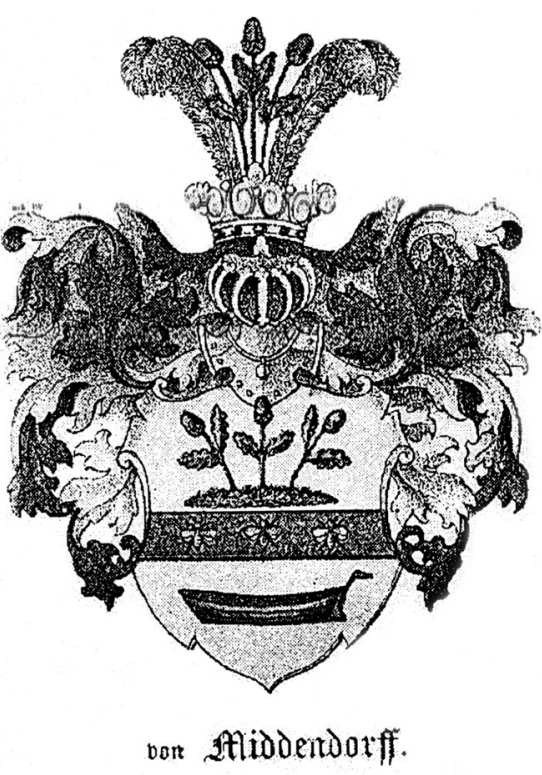

The coat of arms of the Middendorff family five children. The eldest son Ernst (1851-1916), who also studied at the University of Tartu, became one of the best-known ornithophenologists and founders of the bird-watching network.

The Estonian, Livonian and Russian branches of the Middendorff family had different coats of arms. The coat of arms of the Livonian family is divided into three by a boom upon which three bees are sitting. On the upper part of the shield, there are acorns, on the lower part, however, a boat. The crest and the mantle are golden. The image of the boat was added to the family coat of arms after the Taimyr expedition.

\section{RESEARCH}

Already as a young man, Alexander Theodor von Middendorff offered himself as a companion to J. J. F. W. Parrot for his voyage to Nordkapp but was refused.

An essential role in Alexander Theodor von Middendorff's further activities belonged to close acquaintanceship with Karl Ernst von Baer (1792-1876), who was then one of the leading academicians of St Petersburg Academy of Sciences. In 1839, Middendorff accompanied Baer on his journey to Finland, and during the summer vacation of 1840 , he participated in Baer's expedition to Novaya Zemlya and Lapland, where they did not reach their destination because of a 
storm but explored the Murman Coast. Middendorff established that the Kola River does not flow from the south-east to the north-west like shown on the maps then but from the south to the north.

From 1842-1845, however, Middendorff himself led an expedition arranged by the St Petersburg Academy of Sciences to Siberia and the Far East. With the mediation of K. E. von Baer, this brought him international recognition. The expedition team had four members: its chief was A. Th. Middendorff; the cartographer was military topographer V. V. Vaganov from Omsk; naturalist and artist - the Danish forester T. E. Brandt and preparator - ethnic Estonian M. Fuhrmann from Pööravere manor. The most difficult stage was the exploration of the Taimyr tundra from March to September 1843, as part of the route covered the area which even the local Nenets were afraid to enter. Across Lake Taimyr and along the river bearing the same name, the expedition reached the Arctic Ocean. The return trip was particularly gruelling, as the lake froze, and the boat could not be used. Middendorff became ill and remained in a temporary shelter with his collections, while his companions went to search for help. The snowstorm, however, did not allow them to return immediately. Middendorff himself described his experiences as follows, "After the first three days, I was so feeble that I could not leave my shelter on the following three days.... Day followed day with wearisome monotony ... I understood that I could only rely on my dwindling strength; I almost felt as if I had been buried... (then a snowstorm followed that lasted for several days) ... I was seized by indescribable fear of madness; this unbearable fear oppressed my heart. Fighting with hunger and freezing, I had still waited for my rescuers, but in vain. Then, like a bolt out of the blue, an idea occurred to me. I quickly sacrificed the remaining firewood and melted three glasses of water from snow; by then the beneficial fire had gone out again. Thereafter, I acted resolutely - I poured the spirit from one of the specimens into water and drank it. With this drink, new life entered me. ... Soon I fell into deep sleep. I don't know how long it lasted. When I woke up, I felt fresh and recovered. I took my horsehair-thread needle from the box and sewed a pair of boots for myself" [6: 181-182, 4: 147-148].

Quite soon after leaving his shelter he met his helpers but suffered from the consequences of starvation and freezing to the end of his life.

Work continued in Yakutsk where the so-called Shregin shaft - a well that reached the depth of 116 metres in the frozen ground - offered a unique opportunity for studying the characteristics of permafrost. Then, Middendorff decided to explore the coast of the Sea of Okhotsk. From there, the expedition returned along the Stanovoy mountain range, which, according to the 1689 
treaty between Russia and China had been appointed to be the border between the two countries. The Russian authorities were highly interested in Middendorff's observations as a great part of the winter expedition proceeded secretly in the territory then belonging to China [4: 148]. The expedition ended triumphantly. Even before Middendorff returned to St Petersburg, boxes with geological specimens, 8500 herbarium specimens of plants, 445 skins of mammals and 495 mammals preserved in spirit, 562 stuffed birds, 294 specimen of fishes, 500 invertebrates preserved in spirit, etc. were sent to the Academy of Sciences [9: 14]. To analyse the expedition materials, experts in narrower specialities were engaged (Baer, Lenz, Meyer, Helmersen, etc.) and, from 1848-1875, the four-volume major work Reise in den äussersten Norden und Osten Sibiriens was published. In Russian, only the fourth volume was published (1860-1878) [4: 148]. Middendorff's contribution included 3000 pages on permafrost, most of the part on fauna and the whole fourth volume - Siberian geography, biogeography and its peoples' ethnography. The books on the Siberian expedition also include an atlas (1859) with detailed maps of the territories explored as well as maps of the major settlements and peoples of North Siberia [4: 148].

The expedition lasted from November 1842 to 20 March 1845. Already on 2 May, K. E. von Baer, F. F. Brandt and P. N. Fus made a proposal to the Department of Physics and Mathematics at the Academy of Sciences to elect A. Middendorff Adjunct of Zoology. The election took place on 23 May, and on 2 August, the general meeting of the Academy confirmed its results.

\section{THE MAMMOTH ISSUE}

In 1806, Michael Adams, Adjunct of St Petersburg Academy of Sciences, brought a fully preserved skeleton of a mammoth and some of its soft tissues to St Petersburg from the estuary of the Lena River. The material was tidied up and put on display at the zoology museum of St Petersburg Academy of Sciences. Unfortunately, Adams' report described the location of finding the mammoth and the local conditions imprecisely and ambiguously; therefore, no solid conclusions could be drawn. At that time, most zoologists and geologists were of the opinion that the mammoth was a southern animal whose corpses were carried to the coast of the Arctic Ocean by the great Siberian rivers, and their remnants were preserved there in sea or river ice. K. E. von Baer, however, was convinced that the mammoth was a northern animal whose extinction was caused by the abrupt cooling of climate, which also led to the formation of permafrost in Siberia where mammoths were preserved. From 1842-1845, 
to study permafrost and to clarify the mammoth question, Baer organised an expedition to the northern and eastern regions of Siberia. During the expedition, Middendorff managed to concretise the facts about the precise location where Adams had found the mammoth, but not to the extent that Baer's questions could be fully answered. In addition, during his own expedition, he found the remnants of a mammoth on the lower reaches of the Taimyr River (1843); this convinced him, contrary to Baer, that the mammoth was a southern animal [10: 2/6-3/6]. From the expedition to Siberia, Middendorff also brought along numerous ethnographic objects. Alexander von Middendorff was the first to provide truthful information on permafrost and also to determine the approximate borders of permafrost on the huge territory of Siberia [9: 14].

\section{BACK IN ST PETERSBURG}

After the arrival of the expedition, a great banquet was arranged in honour of Middendorff on 1 April 1845. There, the explorers decided to found the Russian Geographical Society. Now, the St Petersburg Academy of Sciences stopped arranging expeditions, as this was done by the Society, universities and other institutions. Middendorff, however, rendered assistance in preparations for the following expeditions [2: 5]. In 1845, Middendorff was still only 30 years old, an energetic, successful, famous and shiny personality. In 1847, the publication of volumes describing his expedition to Siberia began in German; these brought him widespread fame [1: 171]. In recognition of Middendorff's expedition to Siberia and the Far East, Middendorff was given the gold medal of London Geographical Society in 1846 and was elected honorary member of Berlin Geographical Society. From 1848-1875, the account of the expedition led by Middendorff was published under the title of Reise in äussersten Norden und Osten Sibiriens während der Jahre 1843 und 1844 (A Journey to Northern and Eastern Siberia from 1843-1844). This major publication by Middendorff is considered one of the first best ecological-geographical monographs in the world. As Middendorff had stayed away from the habitual company of intellectuals for three years, he was eager to hear the science news of the world and to learn about the achievements of his colleagues. Middendorff invited a select company of scientists to his home. First, some presentation was listened to; this was followed by a discussion; then tea was served, seldom, on frosty nights, also punch. In a cosy atmosphere, they smoked pipes and discussed topical events and problems. Some presentations were later published in print. Definitely, the best-known name in the company was K. E. von Baer, but the evenings were also 
attended by Count Alexander von Keyserling (naturalist and politician, Corresponding Member of St Petersburg Academy of Sciences, Chief of the Estonian Knighthood from 1857-1862 and Curator of Tartu School District from 1862-1869), August von Oettingen (the later Governor of Livonia), Friedrich Georg Wilhelm Struve (astronomer and Academician of St Petersburg Academy of Sciences), Baron Ferdinand von Wrangel (seafarer and explorer), Ferdinand Johann Wiedemann (linguist and Academician of St Petersburg Academy of Sciences) and several other persons related to the University of Tartu or Estonia. In his later years, Middendorff seemed to become exhausted, and severe colds during his expeditions to Siberia had caused damage to his throat and vocal cords. He temporarily lost his voice and could not stay in company for a longer time. Then quadruple chess was played in a smaller company. One of the few Russians invited to Middendorff's evenings was Academic Secretary Konstantin Veselovski [1: 171].

Middendorff also explored Iceland and Novaya Zemlya (1867), the Baraba steppe (1870), the Fergana Valley (1878) and the Canary Islands. In 1883, he took an expedition to the guberniyas of Northern Russia to investigate and improve the situation of cattle-breeding. The research results were published in 1884 in the book A Study of the Current Situation of Cattle-breeding in Russia. The study was considered very precise and extensive for that time. A. Th. von Middendorff also reached theoretical conclusions. He created a detailed methodology for studying cattle breeds by means of measuring, photographing and describing animals, taking craniological measurements and studying the characteristics of meat by slaughtering. In ornithology, he is known for his monograph on bird migration (1855), which was the first on this theme in Russia. As said above, in 1845, A. Th. von Middendorff was elected Adjunct of St Petersburg Academy of Sciences, in 1850 Extraordinary and in 1852 Ordinary Academician in zoology. In 1855, he was elected permanent Secretary of the Academy. He held this post until 1857 when he left because of deteriorating health and disagreements within the Academy. In 1859, A. Th. von Middendorff was elected President of the Free Imperial Economic Society. From 1845, he was a member of the Russian Geographical Society and in 1883 was elected its honorary member. From 1862-1882, Middendorff was President of the Livonian Non-profit-making Economic Society. In the studies of Livonian agricultural history arranged by this organisation of large landowners, the weekly Baltische Wochenschrift published from 1863-1915, starting publication under Middendorff's presidency, was of great significance [2: 6].

Alexander von Middendorff had direct contacts with the families of the ruling elite. In 1852, Middendorff taught hippology to Grand Dukes Nikolai 
Nikolayevich and Mikhail Nikolayevich. The Grand Dukes liked his teaching so much that they awarded him a brilliant ring. Until 1859, he taught natural sciences to Alexander II's son Nikolai Alexandrovich. In 1867, however, he travelled on the Mediterranean Sea and the Atlantic Ocean and, in 1870, on the White Sea and the Barents Sea together with Alexey Alexandrovich [12: $99,126,163]$.

In 1868, Alexander von Middendorff's wife Hedviga died, and he had to take care of his children alone. Often, the children accompanied him during his journeys, but they also had to stay with the parents and sister of his deceased wife. His favourite daughter was Hedviga. In 1874, he spent much time at Pööravere, as because of the marriage of his son Ernst, Hellenurme manor was left to him. From 1876, Middendorff lived at Pööravere with Hedviga and Kristina, and Hedviga managed the household. In 1885, when Middendorff became severely ill, he came to live with the family of his son Ernst at Hellenurme [12: 89].

As a landlord, Middendorff was an innovative and talented economist. He introduced the three-field system, grew potatoes and clover for animal fodder. He procured ploughs with the newest construction. He dried the bogs on his lands by means of drainage and used peat as a fertiliser. He also practised gardening and tried to grow exotic fruit. At Hellenurme, spirits, kerosene, roof tiles, thread and fabrics were produced. He gave his peasants land for rent and paid them wages for work in his household. He also founded a so-called "oldage fund" to secure his workers with means at the end of their lives. Joining it was initially voluntary but later obligatory. Middendorff dealt particularly intensively with animal husbandry.

The Siberian expedition had left its traces on Middendorff's health. In 1883, his son Ernst bought his father a typewriter, as because of his trembling hand, he was unable to write. His strong body that had endured both Siberian cold and the heat of the Fergana valley was tired and his legs began to fail him.

On 2 June 1887, he celebrated the $50^{\text {th }}$ anniversary of the defence of his doctoral thesis at Hellenurme in the circle of his family. The press published articles about him, and on 28 May 1887, Dorpat University elected Middendorff its honorary doctor. The Academy of Sciences sent him a citation of honour. He was decorated with St Vladimir's Order of the second class. Congratulations also arrived from elsewhere, e.g. from Przhevalsky, Toll and Schrenk [12: 192].

In the early 1890s, Middendorff could move only in the wheelchair. At the end of 1892, he was unable to walk, sit and read. He had always taken responsibility for everything that surrounded him - when seeing that the map of Lapland was wrong, he wrote an article and published it twice; when travelling near the Sea of Okhotsk, he tried to find what could be done for the Amur to 
become a Russian river; he tried to raise the level of agriculture; he contributed to the railway reaching the Baltic provinces; he even managed to fight Siberian plague, but now, he was fading away.

Alexander Theodor von Middendorff died at Hellenurme on 28 January (16 January Old Style) 1894. The old scientist's funeral became a day of mourning for his old friends and the people of several villages. The funeral took place six days after his death. The relatives and friends had gathered in the manor house for mourning. Wreaths had been sent by the Siberian Geographical Society, the St Petersburg Academy of Sciences and the Imperial Economic Society. He was also commemorated with wreaths by several farmers' societies, students' fraternities, etc.

Despite bad weather, many people had gathered. Farmers of Hellenurme carried the coffin on their shoulders from the balcony of the manor to the burial place of the Middendorff family. The funeral service was conducted by Rongu pastor Hansen; the choir sang several songs [9: 18].

After his death, the Postimees newpaper (No. 13, 1894) wrote about A. Th. v Middendorff: "After Dr Karl Ernst von Baer's death, there has been no man whose name would have shone so brightly in the world of science." In the Olevik newspaper (No. 5, 1894), we can read: "He was always kind and friendly to the people of his own villages and others, and did not have a big opinion of himself because of his high honour and fame; so each child could speak to him like to one's own father. He also took care of the schools in his villages and gave them free building materials and covered the expenses for the upkeep of the schools" [2].

Seventeen species of animals and plants have been named after A. Th. v. Middendorff. Middendorff's name has been given to a bay on the Taimyr Peninsula and to a cape on Novaya Zemlya.

The internationally renowned naturalist Eerik Kumari (1912-1984) has written, "Along with K. E. v. Baer, A. Th. v. Middendorff is one of the greatest naturalists in $19^{\text {th }}$-century Russia. Like Baer, Middendorff represents the type of naturalists who, in addition to encyclopaedic knowledge, have deep erudition and are able to contribute to several fields. His areas of interest included geography, hydrology, climatology, botany, zoology, agriculture and ethnography (partly even linguistics) - so broad was his scope of interests" [2]. 


\section{REFERENCES}

1. Ambus A. (2005). Middendorffi õhtud. Peterburi haritlaskonna seltsielus XIX sajandi teisel poolel. Keel ja Kirjandus, 3, 171-181.

2. Karelson M. (1994). Sada aastat akadeemik Alexander Theodor von Middendorffi surmast. http://agrt.emu.ee/pdf/1994_1_karelson.pdf

3. Das Lexikon der Entecker - Die bedeutendsten Pioniere aller Zeiten. http://www.amazon.de/Das-Lexikon-Entdecker-bedeutendsten-Pioniere/ $\mathrm{dp} / 3866901011$

4. Mardiste H. (2006) Raamat Siberi uurijast ning Liivimaa põllumehest ja ühiskonnategelasest. Tuna, 3, 146-149.

5. Middendorff, Alexander Theodor von, baltisaksa-eesti päritolu loodus- ja põllumajandusteadlane. www.elus.ee/planeetmaa/?show $=34 \&$ do $=1$ Grewingk

6. Middendorff A.Th.V. (1987). Reis Taimõrile. Tallinn: Eesti Raamat, 181-182.

7. Päid K. (1968). Akadeemik A. Middendorff Hellenurmes. Teaduse ajaloo lehekülgi Eestist I. Tallinn, 153-168.

8. Päid K. (1993). Akadeemik Al. Th. von Middendorff meile ja meie temast. Kaseküla; Elva: Elva Muuseum.

9. Pallon S. (2000). Hellenurme aegade peeglis. Valga: Litero.10.

10. Tammiksaar E. (2012). Baltisakslased olid agarad mammutite uurijad. Eesti Loodus, 8, 8-13.11

11. Tartu Ülikooli ajalugu II. 1798-1918. Koostanud Karl Siilivask. Tallinn: Eesti Raamat, 1982.12.

12. Сухова Н.Г. [Sukhova N.G.], Таммиксаap Э. [Tammiksaar E.] (2015). Алексанр Федорович Миддендорфф. К двухсотлетию со дня рождения [Aleksandr Federovič Middendorff. K dvukhsotletiju so dnja roždenija]. Санкт-Петербург, Нестор-История.

\section{Address for correspondence:}

Maie Toomsalu

Institute of Biomedicine and Translational Medicine

Department of Anatomy

University of Tartu, Tartu, Estonia

ravila Street 19, 50411 Tartu, Estonia

E-mail: maie.toomsalu@ut.ee 